\title{
Cognitive-affective predictors of green purchase intentions among health workers in Nigeria
}

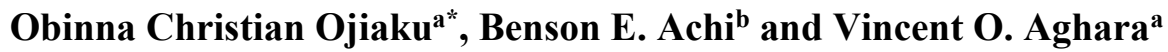

${ }^{a}$ Department of Marketing, Nnamdi Azikiwe University, Awka, Anambra State, Nigeria ${ }^{b}$ Department of Marketing, Imo State Polytechnic, Umuagwo, Nigeria

\section{H R O N I C L E \\ A B S T R A C T}

Article history:

Received: May 16, 2018

Received in revised format: May

24, 2018

Accepted: July 31, 2018

Available online:

August 1, 2018

Keywords:

Green product

Sustainability agenda

Environmental concern

Attitude

Purchase intention

Nigeria

\begin{abstract}
Consumers' consumption culture of the twentieth century has culminated into environmental degradation and its adverse consequences on health and the ecosystem. Despite these concerns, consumers still fail to purchase environmentally-friendly or green products due to the lack of awareness and belief about the benefits of such products. This study seeks to understand consumers' attitude towards green products by investigating the effect of consumers' green product knowledge, green product belief, environment affect and environmental concern on green product purchase intention drawing on the cognitive-affect-behaviour model. Multiple regression analysis was used to analyse the data from 348 Health workers from a South-eastern Health Institution in Nigeria and examined the proposed hypotheses. The result shows that green product purchase intention was significantly influenced by green product knowledge and environmental affect but no significant effect was found for green product belief and environmental concern. Environmental effects had the most impact on green product purchase intention. Therefore, it is recommended that marketers focus their marketing campaigns towards educating consumers on the availability and benefits of green products by using eco-labels and emphasizing the health and environment benefits of green products; appealing to consumers' morals and emotions in marketing campaigns for green products to spur consumers' interest in green products and adopting a green lifestyle.
\end{abstract}

\section{Introduction}

\subsection{Background to the study}

Globally, consumers' consumption culture of the twentieth century has culminated into environmental degradation and its adverse consequences on health and the ecosystem. The consequences of environmental degradation manifest in the forms global warming, depletion of natural resources, air, water and land pollution, noise, acid rain and desertification (Chen \& Chai, 2010). For instance, the increased cases of flooding experienced in most parts of Nigeria recently are pointers to the effects of environmental degradation and has been attributed to improper disposal of solid waste from food and household items (National Environmental Standard and Regulatory Agency, 2016). Accordingly, concerns about the environment have become an issue for political and academic discourse (Rahbar \& Wahid, 2011; Fraj \& Martinez, 2007).

* Corresponding author. Tel.: +2348062678341

E-mail address: oc.ojiaku@unizik.edu.ng (O.C. Ojiaku) 
As a consequence, stakeholders especially consumers in Europe and America, are particularly concerned about the protection of the environment (D'Souza et al., 2007) and have also channelled their growing concern for the environment through the demand for environmentally friendly or 'green products' (Suki, 2016a). These development have made businesses move beyond mere compliance with environmental regulations to exploiting green issues as a marketing strategy (Chan \& Choi, 2010) by introducing alternative products classified as 'green products' (D'Souza et al., 2007). Bonini and Oppenheim (2008) argued that the consumption of green products could help in achieving environmental sustainability.

Green or environmentally friendly products, are products that incorporate the strategies of recycling, recycled content, reduced packaging, uses less toxic materials and will not pollute the environment or deplore natural resources (Shamdasani Chon-Lin, \& Richmond, 1993; D’Souza et al., 2007). Previous research has documented consumers' positive attitude towards green products (Benson \& Hiller Connell, 2014; Tanner \& Kast, 2003; Vermeir \& Verbeke, 2006). Despite concerns about the environmental impact of consumptions, consumers still fail to purchase green products (Gupta \& Ogden, 2009). The failure of consumers to purchase green products has been attributed to consumers' inability to make informed choices with respect to their expressed concerns due to poorly communicated benefits of green products on the one hand, and the scarcity and convenience of getting green products on the other hand (Vermeir \& Verbeke, 2006). Evidence has shown that only a few consumers are knowledgeable about and understand the green characteristics of products (Vermeir \& Verbeke, 2006; Odia \& Adekunle, 2017). Masi et al. (2015) report that Nigerians purchase only about $5 \%$ of green products. Therefore, consumers' awareness and belief about the benefits of green products is an important factor in their purchase decision.

Furthermore, with the rapid expansion of green consumerism mostly in developed economies and its gradual foothold in developing nations such as Nigeria, the 'green consumer' segment who favour environmentally friendly product has started to emerge (Yadav \& Pathak, 2017). However, there is evidence to suggest that firms can hardly predict with some level of certainty how these consumers' segment react to green products due to their changing preferences, unfavourable perception of green products, suspicion of green claims and the perceived high cost that is associated with green products (D'Souza et al., 2007; Masi et al., 2015). This development threatens the growth of green marketing domain (Eze \& Ndubuisi, 2013) and its adverse consequences on the environment. Therefore, it is useful from a marketing standpoint to investigate how consumers make informed choices about green products (Cheah \& Phau, 2011).

Though consumers' green consumption behaviour is well documented in the literature, most of the studies are of Western Adaptation. Therefore, following the varied environmental concerns, belief and attitude of developing nations (Paul et al., 2016) such as Nigeria, further research is needed to ascertain consumers' attitude towards green product (Suki 2016b; Joshi \& Rahman, 2015) to mitigate further environmental degradation (Paul et al., 2016). Therefore, this study draws on the cognitive-affectivebehaviour attitude model to understand consumer attitude towards green products in Nigeria. Specifically, this study seeks to ascertain the effect of green product belief, green product knowledge, environmental affect, and environmental concern on green purchase intention among health workers from a South-eastern Health facility in Nigeria.

\section{Review of related literature}

Attitude according to Allport (1935) is defined as: 'A mental and neural state of readiness, which exerts a directing, influence upon the individual's response to all objects and situations with which it is related' (p. 798). The cognitive, affective-behaviour model is the traditional view of attitude structure used to describe people's perception, awareness, feelings or emotional responses, judgment, opinion or behaviour about environmental-related problems (Milfont \& Duckitt, 2010). The cognitive component consists of a person's knowledge or beliefs about a subject matter, the affective component refers to the people's emotional reaction or feelings about specific attributes or overall objects. The third component, the behavioural or conative component consists of one's intention to act in certain ways or the actual behaviour 
towards an attitude object. According to the CAB model, consumers' decisions following the Standard Learning Hierarchical sequence (Liu et al., 2017), begin with cognitions (personal beliefs, thoughts and perceptions, meaning or attitudes about a given issue or object), followed by affect (feelings or emotions that individuals have with respect to an issue or object) and leading to behaviours (either intentions to act or actual actions) behaviour (Liu et al., 2017). That is, people's attitudes affect their thoughts (the cognitive function) and feelings (the affective function), and thus influence behaviour such as purchasing behaviour (Pickett-Baker \& Ozaki, 2008). Previous studies have shown that environmental affect exert greater influence on behaviour than environmental knowledge (Fraj \& Mahrej, 2007; Kanchanapibul et al., 2014). Though the Theory of planned behaviour has been demonstrated to show greater predictive power than the CAB model (Liu et al., 2017), it is has been criticized for not accounting for the affective element found to influence ecological behaviour (Joshi \& Rahman, 2015). This study adopts the CAB model and argues that consumers' knowledge and belief about green product will affect behaviour, and consumers' environmental concern and affect will also affect consumers' intention to buy green products.

\subsection{Green marketing}

Green marketing is believed to be one of the major contemporary business trends (Ku et al., 2012) with the strategic intent of communicating the environmental responsive behaviour of companies (Cheung et al., 2015). Green marketing consists of all planned activities designed to generate and facilitate exchanges in order to satisfy human needs and desires with the least impact possible on the environment (Polonsky, 2004; Padel \& Foster, 2005). According to Jain and Kaur (2004), green marketing refers to marketing activities developed to stimulate and maintain consumers' environmental attitudes and behaviours. Peattie and Charter (2003) defined green marketing as the holistic management process responsible for identifying, anticipating and satisfying customers and societal needs in a profitable and sustainable manner. Green marketing is generally concerned with the environmental and societal impact of marketing activities.

Green marketing incorporates a broad range of activities, from the R\&D, Design, manufacturing process, and packaging to advertising (Cheung et al., 2015) and is concerned with the impact of production and consumption on quality of life and the ecosystem (Akehurst et al., 2012; Ajzen, I2011). Companies adopt the green marketing orientation to leverage on green market opportunities, build corporate reputation, improve product value, enhance its competitive advantages and comply with environmental trends (Chen, 2008). Green marketing strategy helps attract green conscious consumer and is a component of corporate social responsibility with an emphasis on the triple bottom line accounting of profit, planet, and people (Choudhary \& Gokarn, 2013; Cheung et al., 2015). Green-oriented firms, therefore, develop green products and services in order to achieve consumers and society's satisfaction (Akehurst et al., 2012).

\subsection{Conceptual Framework and Hypotheses}

\subsubsection{Green product beliefs}

Despite the emergence of green movement, consumers are still sceptical about green brands. Consumers are particularly uncertain about green products attributes and features and often doubt their environmental benefits and performance (Leonidou \& Skarmeas, 2017). Therefore, the belief consumers hold about green products performance will translate into their willingness to buy (Leonidou \& Skarmeas, 2017). In other words, consumers' belief about green brands informs their decision to adopt pro-environmental behaviour. Green product belief is a cognitive attitude construct that refers to consumers' belief about the consequences of buying and using green products. Thus, consumers who hold a strong belief about buying and using environmentally friendly products will have a positive attitude towards the behaviour and be more willing to buy and use green products (Zabkar \& Hosta, 2013; Liu et al., 2017). For example, Mainieri et al., (1997) found consumer beliefs to positively predict the number and types of green products purchased. Similarly, Kang et al. (2013) found consumers' belief about buying and wearing organic cotton apparel to positively affect purchase intention. Therefore, adopting a green positioning strategy 
and fostering green brand belief among consumers will significantly improve consumers' green consumption behaviour (Suki, 2016b). Accordingly, we hypothesize the following:

\section{$\mathrm{H}_{1}$ : Consumers' green product belief will significantly influence green purchase intention.}

\subsubsection{Green product knowledge}

Product knowledge refers to the sum of product-related information stored in consumers' memories (Kang et al., 2013) while familiarity is the accumulated consumption experiences (Liu et al., 2017). Green product knowledge consists of consumers' familiarity with green products and their features as well as their subjective evaluation (Liu et al., 2017). Green purchases are complex because consumers need to evaluate environmental attributes alongside conventional product on attributes such as price, quality, performance, and availability (Kashmanian et al., 1990). Therefore, a lack of relevant product knowledge can be a significant barrier to green consumption (Liu et al., 2017). Green product knowledge provides information about the unique green attributes of products and its benefits to the overall environment to the consumer (Suki, 2016b).

Consumers expect to receive reliable information about environmental issues to boost their green product knowledge and facilitate green product purchases (Suki, 2016a). The amount of green product knowledge consumers possesses will affect their intention to buy green products. Prior studies have shown a positive relationship between green product knowledge and consumer behaviour (Suki, 2016a; Kumar \& Ghodeswar, 2015). This study focuses on green product knowledge rather than a general environmental knowledge per se. Thus, we hypothesize the following:

\section{$\mathrm{H}_{2}$ : Consumers' green product knowledge will significantly influence green purchase intention.}

\subsubsection{Environmental affect}

Affect is a component of attitude which refers to an individual's emotion and feelings towards an object. The literature suggests that affect significantly influences attitude and the results of the causal relationship between attitude and behaviour are stronger when affect is treated independently of attitude (Allen, Machleit, \& Kleine, 1992; Fraj \& Martinez, 2007). Thus, "The relationship between attitudes and behaviour will be shaped by the affect influence" (Fraj \& Martinez, 2007, p.31).

In this study, environment affect is investigated based on consumers emotional values on which attitudes are based (Kanchanapibul et al., 2014; Suki \& Suki, 2017). We conceptualize environmental affect differently from environment concern, even though the literature used the two concepts interchangeably with both concepts relating to the affective component of attitude. The rationale is that a key motive for consumers to become involved in green issues is their affective response to environment issues (Kanchanapibul et al., 2014) which manifest as positive emotional values and receptive green purchase decisions (Lin \& Huang, 2012). Such affective response motivates consumers to forgo the consumption of conventional products for green products because they believe that doing so will help protect the environment and lead to sustainable development (Suki \& Suki, 2015). Prior studies show a strong positive relationship between environment affect and green buying behaviour (Kanchanapibul et al., 2014; Fraj \& Martinez, 2007). Therefore, we hypothesize that

\section{H3: Consumers' environmental affect will significantly influence green purchase intention.}

\subsubsection{Environmental concern}

Environmental concern refers to the extent people are aware of environmental problems, support efforts to solve such problems, and are willing to personally contribute to the solution (Chan \& Lau, 2000; 
Dunlap \& Jones, 2002). According to Kim and Han (2010), environmental concern is one's apprehensions about diverse environmental problems such as environmental degradation, depletion of natural resources etc. Environmental concern is an important source of motivation for sustainable behaviour (Grunert et al., 2014), as it in induces a sense of responsibility and activates a personal norm to become environmentally conscious (Fujii, 2006). Therefore, environment concern is a consumer's affective response to environment problems. Researchers have argued that consumers concerned about the environment may not necessarily buy eco-friendly products (Kaiser, Wolfing, \& Fuhrer, 1999; Pickett-Baker \& Ozaki, 2008). Purchasing green product will mean making a trade-off between environment concern and the attributes of conventional products (Joshi \& Rahman, 2015). However, environmental concern motivates consumers to investigate green products (Joshi \& Rahman, 2015). Previous studies have reported weak to moderate relationship between environmental concern and green purchase intention (Kim \& Choi, 2005; Prakash \& Pathak, 2017; Joshi \& Rahman, 2015). Nevertheless, environmental concern is an important predictor of green purchase intentions. Accordingly, we hypothesize that:

\section{H4: Consumers' environmental concerns will significantly influence green purchase intention.}

\subsubsection{Green Purchase Intention}

Green purchase intention is a consumer's intent or actual purchase of products that are not harmful to the environment once they are aware of its environmental-friendly attributes (Huang et al., 2014). Intentions capture the motivational factors that influence green purchase behaviour of consumers (Ramayah, Lee, \& Mohamad, 2010). Consumers, who profess environmental consciousness, will purchase only green products, demonstrate a willingness to pay more for environmentally-friendly products, and buy products that will save water, save energy and reduce solid waste. The inclination to buy green products will be affected by consumers' knowledge of green attributes in products with 'green claims', their belief in the environmental benefits of green products, the level of their concern towards the environment and their affective response towards the environment. For instance, Kumar et al. (2017) report a positive relationship between attitude and green purchase intention

\section{Research Method}

A survey design method was adopted to elicit responses from a cross-section of 348 Health workers in a Health facility in South-eastern, Nigeria.

\subsection{Measurement}

The measurement instrument for data collection was a structured questionnaire. The questionnaire is structured into two sections. Section A contains demographic questions, while section B comprises on questions eliciting responses based on the study construct namely environmental knowledge, belief, environmental concerns, green product knowledge. All items of the questionnaire were adapted from existing literature. All items were based on a 5 - point Likert scale questions ranging from $5=$ strongly agree to $1=$ strongly disagree.

\subsection{Data collection}

A pilot test was conducted using a convenience sample of 30 post graduate students. Based on the pilot testing Cronbach's alpha was used to estimate the reliability of the instrument while the measures were face validated by senior academics in marketing and environmental sciences. In the main study, a mixed method of random sampling and convenience sampling was used to collect data from Health workers using self-administered questionnaire. Due to the busy schedule of most health workers, some of the respondents acquainted with the researcher were interviewed while others were randomly interviewed. Copies of the questionnaire were dropped and later picked up by allowing a time frame of 7 days. In total 371 copies of the questionnaire was distributed while 348 valid responses were used in the final analysis 
representing a response rate of 94 per cent. The high response rate was achieved because trained interview was employed to follow-up on the respondents and a time span of 8 weeks was allowed for data collection. Demographic characteristics of the respondents' show that a majority of the respondents are female (53\%) and 47\% male. Most of the respondents are between the ages of 36 and 50 years $(46 \%)$ and 20 - 35years (39\%) respectively. More than 85\% have a Degree with about $10 \%$ having a Ph.D. degree and most earning between 50,000 and 150,000 Naira per month (44\%).

\section{Results}

\subsection{Factor Analysis}

A Principal component Analysis was computed to reduce the data using varimax rotation, eigenvalue set at greater than 1 and factor loading greater than 0.5. Six items relating to green product knowledge loaded on the first factor hence labelled 'green product knowledge'. The second factor consists of 5 items relating to environmental concern and labelled 'environmental concern'. However, one item 'It frightens me to imagine that many of the products I use disrupt the environment" loaded on two factors and was dropped. Four items loaded on the third factor and labelled 'green brand belief". One item "green products would enable implementation of green initiatives" relating to green product belief loaded on the first and third factor and was dropped. The fourth factor contains three items relating to environmental affect and therefore labelled 'environment affect'. Finally, the three items relating to 'green purchase intentions loaded' on the fifth factor and labelled 'green purchase intention". The factor explains more than $68 \%$ of the variance and the reliability measures were all above 0.70 Benchmark (Nunnally \& Bainstein, 1994). Summary of the factor analysis and reliability measurement is shown in Table 1 below.

Table 1

Factor Loading and Reliability of the Construct

\begin{tabular}{|c|c|c|c|c|c|c|c|}
\hline & 1 & 2 & 3 & 4 & 5 & $\begin{array}{l}\text { Explained } \\
\text { Variance } \\
(\%)\end{array}$ & $\begin{array}{l}\text { Cronbach } \\
\text { Alpha } \\
\text { (a) }\end{array}$ \\
\hline \multicolumn{8}{|l|}{ Green Product Knowledge } \\
\hline I know how to find environmental-related information on green brands & .886 & & & & & & \\
\hline I know of products that are associated with protecting the environment & .799 & & & & & & \\
\hline I can think of some brands when talking about environmentally-friendly products & .722 & & & & & & \\
\hline I know of products that are made of recyclable materials & .699 & & & & & & \\
\hline I am knowledgeable of green products & .556 & & & & & & \\
\hline I am familiar with green products & .554 & & & & & 29.9 & .87 \\
\hline It frightens me to imagine that many of the product I use disrupts the environment & & .512 & & & & & \\
\hline Humans are really abusing the environment & & .852 & & & & & \\
\hline When I think of the way humans are destroying the environment, I get angry and frustrated & & .812 & & & & & \\
\hline The balance of nature is easily disrupted, especially by human activity & & .749 & & & & & \\
\hline We should take responsibility for environmental issues as we are the cause of environmental & & .704 & & & & 15.9 & .87 \\
\hline Green product belief & & & .854 & & & & \\
\hline Green products help save or protect the environment & & & .845 & & & & \\
\hline Green products would enable the performance of eco-friendly practices. & & & .664 & & & & \\
\hline Green products make the environment better and clean & & & .636 & & & 10.6 & .86 \\
\hline Environmental affect & & & & .874 & & & \\
\hline Buying green products instead of conventional products would feel like making a good per- & & & & .851 & & & \\
\hline Buying green products instead of conventional products would make me feel like a better & & & & .727 & & 6.4 & .88 \\
\hline Green purchase intentions & & & & & .876 & & \\
\hline Next time I shop for food \& Beverage, I will consider buying products that are less polluting & & & & & .784 & & \\
\hline Next time I shop for food \& Beverage, I plan to switch to a green version of the product & & & & & .686 & 5.8 & .81 \\
\hline
\end{tabular}




\subsection{Hypotheses Testing}

The hypotheses were tested using multiple regression analysis. The ANOVA result shows that the model is a good fit $(\mathrm{F}=13.04, \mathrm{p}<0.001)$ and explains $13.2 \%$ of the variance in the dependent variable. In addition, the Variance Inflation factors are all above 1, showing that the data set is free from multicollinerity problem. The regression result indicates a non-significant effect of green product belief on green product purchase intention $[\beta=.02, \mathrm{p}=0.65]$. Therefore, $\mathrm{H} 1$ is not supported. As expected, green product knowledge significantly predicts consumers' intentions to buy green products $[\beta=.16, p<0.005]$. Hence, $\mathrm{H} 2$ is supported. Contrary to $\mathrm{H} 3$, Consumers concern for the environment shows a non-significant effect on green product purchase intentions $[\beta=.07, \mathrm{p}=1.8]$. Therefore, H3 is not supported. Finally, as predicted, consumers' environmental affect has a significant effect on green product purchase intention $[\beta$ $=.27, \mathrm{p}<0.001]$, thus, supporting H4. Furthermore, the effect of environmental affect shows the strongest prediction on green product purchase intention, confirming its predictive importance in consumer attitude.

Table 2

Analysis of Variance Table for Patronage Intention

\begin{tabular}{|c|c|c|c|c|c|c|c|c|}
\hline & & B & Std. Error & Beta & & & Tolerance & VIF \\
\hline \multirow[t]{5}{*}{1} & (Constant) & 2.468 & .336 & & 7.340 & .000 & & \\
\hline & Green Product Belief & .024 & .053 & .024 & .455 & .649 & .923 & 1.083 \\
\hline & $\begin{array}{l}\text { Green } \\
\text { Knowledge }\end{array}$ & .125 & .043 & .157 & 2.880 & .004 & .846 & 1.182 \\
\hline & Environmental concern & .070 & .052 & .074 & 1.345 & .179 & .836 & 1.196 \\
\hline & Environmental affect & .245 & .049 & .266 & 5.036 & .000 & .910 & 1.099 \\
\hline
\end{tabular}

a. Dependent Variable: Green Purchase intention.

\section{Discussion}

This study investigates how consumers' knowledge and belief about green products, environmental concern and environmental affect influence intentions to buy green products among health workers. The result shows that green product knowledge positively affects consumers' intentions to purchase green products. This finding lends support to Kang et al. (2013), Suki (2016a), Cheah \& Phau (2013) but contradicts Mishra et al. (2017). When consumers are aware and familiar with the green attributes of environmental-friendly products, then they are likely to buy environmental-friendly products. However, contrarily to our finding, Suki (2016a) found green product knowledge to be the strongest determinant of green product purchase intention. Knowledge of green products suggests that consumers can identify eco-labels on green products and commit to protecting the environment.

Regarding the impact of green product belief on green purchase intention as Hypothesized in H3, this was found to have no significant influence on consumers' intentions to purchase green products. This finding confirms Mishra et al. (2017) and Manieri et al. (1997). Green product beliefs suggest that green products have attributes that can help protect the environment or save it from further degradation and enable consumers to perform eco-friendly practices. A plausible explanation for the insignificant effects of green product belief is that though consumers are knowledgeable about green products, they do not hold the belief that it contains attributes that can help protect the environment. Furthermore, despite the prevalent of green initiatives and green claims in products, environment problems still persist. The increased incidence of flooding, environmental degradation and climatic problems are possible pointers to the absence of green product beliefs as a predictor of ecological problems. Moreover, marketers and policy makers in the context of this study, appear to pay only lip services to green initiatives. Marketers do not emphasize the environmental benefits of green products neither do policy makers make conscious efforts to encourage green initiatives in production and consumptions of products. 
The result further shows that environment affect significantly influences green purchase intentions. In line with Fraj and Martinez (2007), environmental affect is the most influential predictor of green purchase intention. This finding confirms the importance of the affective elements in explaining consumer attitude (Joshi \& Rahman, 2015). The finding is in agreement with earlier studies (e.g., Kanchanapibul et al., 2014; Fraj \& Martinez, 2007) but contradicts Suki (2016a). Consumers will forgo the consumption of conventional products for green products as long as it makes them feel they are contributing to a healthier and safer environmental. Thus, consumers' emotions and morality play a significant role in green purchase behaviour. Finally, contrarily to H4, environmental concern shows a non-significant effect on green purchase intention. Previous studies report a positive and significant effect of environmental concern on ecological behaviour (e.g. Koi \& Choi, 2005; Mostafa, 2007; Fraj \& Martinez, 2007; Paul et al., 2016, Praskash \& Pathak, 2017); although, the relationship varies from weak to moderate. We do not find support for the effect of environmental concern contradicting the aforementioned findings. However, our finding supports Mishra et al. (2017). A plausible explanation for this finding is that environmental consciousness is yet to be adequately enshrined in the minds of consumers in the context of this study. In addition, even consumers concerned about the environment, may not buy green products because of the difficulty of identifying green products (Pickett-Baker \& Ozaki, 2008).

\section{Implications}

The opportunities that going green provides, is a source of competitive advantage for firms. Accordingly, marketers can focus their marketing campaigns towards educating consumers on the availability and benefits of green products. Using eco-labels and emphasizing the health and environment benefits of green products in marketing campaigns could provide firms a competitive advantage. More importantly, marketers can offer green products that can compete effectively with conventional products on price, performance and other attributes to the customers and stimulate green consciousness by communicating the benefits of green products to customers. Consumers are likely to buy green products if they are familiar with it. From the policy perspective, policy makers should engage in social marketing programs to increase consumer awareness of the harmful consequences of the consumption of non-green products on health and the environment. In addition, assisting marketers through incentives to encourage the production and marketing of environmentally friendly products and stimulating consumers' consciousness in this respect would be worthwhile. Finally, marketers can appeal to consumers' morals and emotions in their marketing campaigns for green products. When consumers' emotions are spurred into believing that buying green products mean contributing to a better society and a morally right thing to do, consumers may embrace the green lifestyle and opt for green purchases as far as the performance of such products can compete favourably with conventional products.

\section{Conclusion}

As interest towards sustainable production and consumption increases, researchers are seeking ways to better understand the attitude - behaviour gap. This study examines consumers' attitude towards green product form the theoretical lens of cognitive-affective-behaviour model. From the findings, we conclude that green product knowledge is a significant predictor of green purchase intention. Consumers will buy green products if they are aware of its green attributes and familiar with the product. Notably, environmental affect is the most important factor that affects consumers green purchase intentions. Consumers' emotions and morals have a very strong influence on their ecological behaviour. However, mere concern for the environment does not translate into positive ecological behaviour; and consumers are sceptical of green product claims hence they hold an unfavourable belief about the green attributes of the so called green products. 


\section{Limitations and Suggestions for Further Studies}

This paper is not without its limitations. First, the sample is drawn from an occupational group (i.e., Health workers) in one section of the country. This group is assumed knowledgeable and at least conscious of environmental issues. However, it cannot be taken to mean that they are self-professed environmentalist. This could limit the generalization of the result. Future studies involving a cross-sectional study of a more diverse population could be conducted. Second, we investigated the direct relationship between the attitude components of cognitive-affect-behaviour using regression analysis. Future studies could investigate the mediating and moderating relationship between these variables using a more robust technique such as SEM. In addition, the causal relationship between affect-cognitive-behaviour (i.e., feelthink-do) versions of the model can also be investigated. Finally, only one green product category is used in this study. Further studies can be conducted with more green products.

\section{Acknowledgments}

We wish to acknowledge Dr. Titus Okeke and Dr. Shadrach Mouguluwa for the insight provided in preparation of this manuscript. We also acknowledge the medical doctors and other health workers at the University of Nigeria Teaching Hospital, Enugu for participating in the study.

\section{References}

Ajzen, I. (2011). The theory of planned behaviour: reactions and reflections. Journal of Organizational Behavior Free Articles, 50(2), 179-211

Akehurst, G., Afonso, C., \& Gonc, H. M. (2012). Re-examining green purchase behaviour and the green consumer profile: New evidences. Management Decision, 50(5), 972-988.

Allen, C. T., Machleit, K. A. \& Kleine, S. (1992). A comparison of attitudes and emotions as predictors of behaviour at diverse levels of behavioural experience. Journal of Consumer Research 18(4), 493504.

Allport, G.W. (1935) Attitudes. In A Handbook of Social Psychology, Vol. 2 (ed. by C. Murchison), pp. 798-844. Clark University Press, Worcester, MA

Benson, E., \& Y. Hiller Connell, K. (2014). Fair trade consumption from the perspective of US Baby Boomers. Social Responsibility Journal, 10(2), 364-382.

Bonini, S., \& Oppenheim, J. (2008). Cultivating the green consumer. Stanfold Social Innovation Review, 6, 56-61.

Chan, R.Y.K. \& Lau, L.B.Y. (2000). Antecedents of green purchases: a survey in China. Journal of Consumer Marketing, 17(4), 338-357.

Cheah, I., \& Phau, I. (2011). Attitudes towards environmentally friendly products: the influence of ecoliteracy, interpersonal influence and value orientation. Marketing Intelligence Planning, 29(5), 452472

Chen, T. B., \& Chai, L. T. (2010). Attitude towards the environment and green products: Consumers' perspective. Management Science and Engineering, 4(2), 27- 39.

Chen, Y. S. (2008). The driver of green innovation and green image - green core competence. Journal of Business Ethics, 81, 531-543.

Cheung, R., Lam, A.Y.C \& Lau, M.M. (2015). Drivers of green product adoption: The role of green perceived value, green trust and perceived quality. Journal of Global Scholars of Marketing Science, 25(3), 232-245.

Choudhary, A., \& Gokarn, S. (2013). Green Marketing: A means for sustainable development. Journal of Arts, Science \& Commerce, 4(3), 3.

D'Souza, C., Taghian, M., \& Khosla, R. (2007). Examination of environmental beliefs and its impact on the influence of price, quality and demographic characteristics with respect to green purchase intention. Journal of Targeting, Measurement and Analysis for Marketing, 15(2), 69-78. 
Dunlap, R., \& Jones, R. (2002). Environmental concern: Conceptual and measurement issues. In Handbook of environmental sociology, ed. R. Dunlap and W. Michelson. London: Greenwood.

Eze, U.C., \& Ndubisi, N.O. (2013). Green buyer behaviour: Evidence from Asia consumers. Journal of Asian African Studies, 48(4), 413-426

Fraj, E., \& Martinez, E. (2007). Ecological consumer behaviour: An empirical analysis. International Journal of Consumer Studies, 31(1), 26-33.

Fujii, S. (2006). Environmental concern, attitude toward frugality, and ease of behaviour as determinants of pro-environmental behaviour intentions. Journal of Environmental Psychology, 26(4), 262-268.

Grunert, K. G., Hieke, S., \& Wills, J. (2014). Sustainability labels on food products: Consumer motivation, understanding and use. Food Policy, 44, 177-189.

Gupta, S., \& Ogden, D. T. (2009). To buy or not to buy? A social dilemma perspective on green buying. Journal of Consumer Marketing, 26(6), 376-391.

Han, H., Hwang, J., \& Lee, S. (2017). Cognitive, affective, normative, and moral triggers of sustainable intentions among convention-goers. Journal of Environmental Psychology, 51, 1-13.

Huang, Y-C., Yang, M., \& Wang, Y-C. (2014). Effects of green brand on green purchase intention Effects of green brand on green purchase intention. Marketing Intelligence \& Planning, 32(3), 250-268,

Jain, S.K., \& Kaur, G. (2004). Green marketing: an attitudinal and behavioural analysis of Indian consumers. Global Business Review, 5, 187-205.

Joshi, Y., \& Rahman, Z. (2015). Factors affecting green purchase behaviour and future research directions. International Strategic Management Review, 3(1-2), 128-143,

Kaiser, F. G., Wölfing, S., \& Fuhrer, U. (1999). Environmental attitude and ecological behaviour. Journal of environmental psychology, 19(1), 1-19.

Kanchanapibul, M., Lacka, E., Wang, X., \& Kai, H. (2014). An empirical investigation of green purchase behaviour among the young generation. Journal of Cleaner Production, 66, 528-536.

Kang, J., Liu, C., \& Kim, S. H. (2013). Environmentally sustainable textile and apparel consumption: the role of consumer knowledge, perceived consumer effectiveness and perceived personal relevance. International Journal of Consumer Studies, 37(4), 442-452.

Karatu, V. M. H., \& Mat, N.K.N. (2015). Predictors of green purchase intention in Nigeria: The mediating role of environmental consciousness. American Journal of Economics, 5(2), 291-302.

Kashmanian, R.M., Kuusinen, T.L. \& Stoeckle, A. (1990). Source reduction and recyclability: Promotion strategies. Resource Recycling, 9(7), 74-79.

Kim, Y., \& Han, H. (2010). Intention to pay conventional-hotel prices at a green hotel - a modification of the theory of planned behaviour. Journal of Sustainable Tourism, 18(8), 997-1014.

Kim, Y., Choi, S.M., (2005). Antecedents of green purchase behaviour: an examination of collectivism, environmental concern, and PCE. Advances in Consumer Research, 32(1), 592-599.

$\mathrm{Ku}, \mathrm{H}-\mathrm{H} ., \mathrm{Kuo}, \mathrm{C}-\mathrm{C}$., Wu, C-L., \& Wu, C-Y. (2012). Communicating green marketing appeals effectively. Journal of Advertising, 41(4), 41-50.

Kumar, B., Manrai, A. K., \& Manrai, L. A. (2017). Purchasing behaviour for environmentally sustainable products: A conceptual framework and empirical study crossmark. Journal of Retailing and Consumer Services, 34, 1-9.

Kumar, P., \& Ghodeswar, B.M. (2015). Factors affecting consumers' green product purchase decisions. Marketing Intelligence \& Planning, 33(3), 330-347

Laroche, M., Bergeron, J., Forleo, G. B., Laroche, M., \& Bergeron, J. (2011). Targeting consumers who are willing to pay more for environmentally friendly products. Journal of Consumer Marketing, $18(6), 503-520$.

Leonidou, C.N., \& Skarmeas, D. (2017). Gray Shades of Green: Causes and Consequences of Green Skepticism. Journal of Business Ethics, 144(2), 401-415

Lin, P.C., \& Huang, Y.H. (2012). The influence factors on choice behaviour regarding green products based on the theory of consumption values. Journal Cleaner Production, 22, 11-18

Liu, Y., Segev, S., \& Villar, M. E. (2017). Comparing two mechanisms for green consumption : cognitive-affect behaviour vs theory of reasoned action. Journal of Consumer Marketing, 34(5), 442-454, https://doi.org/10.1108/ JCM-01-2016-1688. 
Mainieri, T., Barnett, E. G., Valdero, T. R., Unipan, J. B., \& Oskamp, S. (1997). Green buying: The influence of environmental concern on consumer behaviour. The Journal of Social Psychology, 137(2), 189-204.

Milfont, T.L., \& Duckitt, J. (2010). The environmental attitudes inventory: A valid and reliable measure to assess the structure of environmental attitudes. Journal of Environmental Psychology, 30, 80-94.

Mishra, P., Jain, T., \& Motiani, M. (2017). Have green, pay more: An empirical investigation of consumer's attitude towards green packaging in an emerging economy. R. Sarkar and A. Shaw (eds.), Essays on Sustainability and Management, India Studies in Business and Economics.

Mostafa, M.M. (2007). A hierarchical analysis of the green consciousness of the Egyptian consumer. Psychology \& Marketing, 24 (5), 445-473.

Nielsen (2013). Will a desire to protect the environment translate into action? available at: www.nielsen.com/us/en/newswire/2013/will-a-desire-to-protect-the-environment-translate-into-action-.html (accessed on 9 June. 2017)

Nunnally, J.C., \& Bernstein, I.H. (1994). Psychometric Theory. McGraw Hill, New York

Odia, E. O., \& Adekunle, S. A. (2017). Green purchasing behaviour among nursing mothers. African Journal of Economic and Management Studies 8(2), 147-159.

Padel, S., \& Foster, C. (2005). Exploring the gap between attitudes and behaviour. British Food Journal, $107(8), 606-625$.

Paul, J., Modi, A., \& Patel, J. (2016). Predicting green product consumption using theory of planned behaviour and reasoned action. Journal of Retailing and Consumer Services, 29, 123-134.

Peattie, K. and Charter, M. (2003), “Green marketing”, in Baker, M. (Ed.), The Marketing Book, 5th ed., Butterworth-Heinemann, Oxford.

Pickett-Baker, J., \& Ozaki, R. (2008). Pro-environmental products: marketing influence on consumer purchase decision. Journal of Consumer Marketing, 25, 281-293.

Polonsky, M.J. (1994). An introduction to green marketing. Electronic Green Journal, 1(11) 24-29.

Prakash, G., \& Pathak, P. (2017). Intention to buy eco-friendly packaged products among young consumers of India : A study on developing nation. Journal of Cleaner Production, 141, 385-393.

Rahbar, E., \& Wahid, N.A. (2011). Investigation of green marketing tools' effect on consumers' purchase behaviour. Business Strategy Services, 12(2), 73-83.

Ramayah, T., Lee, J. W. C., \& Mohamad, O. (2010). Green product purchase intention: Some insights from a developing country. Resources, Conservation and Recycling, 54(12), 1419-1427.

Shamdasani, P., Chon-Lin, G., \& Richmond, D. (1993). Exploring green consumers in an oriental culture: role of personal and marketing mix. Advances in Consumer Research, 20, 488-493.

Suki, N. M. (2015). A Structural Modelling on Food Safety Knowledge, Attitude, and Behaviour Among Bum-Bum Island community of Semporna. Food Control, 60(August), 241-246.

Suki, N. M. (2016a). Green product purchase intention: impact of green brands, attitude, and knowledge. British Food Journal, 118(12), 2893-2910.

Suki, N. M. (2016b). Consumer environmental concern and green product purchase in Malaysia: structural effects of consumption values. Journal of Cleaner Production, 132, 204-214.

Suki, N. M., \& Suki, N. M. (2017). Consumption values and consumer environmental concern regarding green products. International Journal of Sustainable Development \& World Ecology, 22(3), 269278.

Tanner, C., \& Kast, S. W. (2003). Promoting sustainable consumption: Determinants of green purchases by Swiss consumers. Psychology \& Marketing, 20(10), 883-902.

Vermeir, I., \& Verbeke, W. I. M. (2006). Sustainable food consumption: exploring the consumer " 'attitude - behavioural intention"” gap. Journal of Agricultural and Environmental Ethics, 19(2) 169194.

Yadav, R., \& Pathak, G. S. (2017). Determinants of consumers green purchase behaviour in a developing nation: Applying and extending the theory of planned behaviour, Ecological Economics, 134, 114 122. 
Zabkar, V. \& Hosta, M. (2013). Willingness to act and environmentally conscious consumer behaviour: can prosocial status perceptions help overcome the gap? International Journal of Consumer Studies, $37,257-264$.

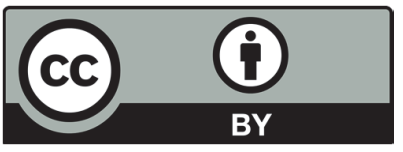

(C) 2018 by the authors; licensee Growing Science, Canada. This is an open access article distributed under the terms and conditions of the Creative Commons Attribution (CCBY) license (http://creativecommons.org/licenses/by/4.0/). 